Accounting academics' perceptions of the effect of accreditation on UK accounting degrees

Peter Ellington and Amanda Williams

Norwich Business School, University of East Anglia, Norwich, United Kingdom

Correspondence details

Amanda Williams

Norwich Business School, University of East Anglia

Email: amanda.williams@uea.ac.uk 


\section{Accounting academics' perceptions of the effect of accreditation on UK accounting degrees}

Students graduating from undergraduate accounting degree programmes in the UK are eligible for and attracted by accreditation available from professional accountancy body (PAB) examinations. The study reviews factual information available from $\mathrm{PAB}$ websites to confirm that virtually all accounting degrees in the UK have accreditation, and many are accredited with two or more PABs. By interviewing 18 accounting academics from a cross section of UK universities, this study verifies the factual information and confirms views expressed in the literature regarding the constraining nature of accreditation on UK accounting degrees. The interviewees confirmed that accreditation is seen as essential for student recruitment to degree programmes and that it leads to degree programmes imitating professional syllabi and examinations, resulting in technical content and didactic methods, which in turns crowds out broader educational activity. While providing a consistent structure and approach to university accounting education in the UK, the consensus view is that accreditation constrains degree programmes leading to a missed opportunity to provide a wider liberal education. It is also found that the legitimacy of awarding exemptions to students with less than good honours should be questioned.

Keywords: accounting education; accreditation; professional accountancy bodies (PABs); liberal education; UK accounting degrees

\section{$1 \quad$ Introduction}

Commentary in the academic literature (see, for example, Apostolou and Gammie, 2014; Duff and Marriott, 2012; Wilson, 2011) consistently criticises professional accountancy body ${ }^{1}(\mathrm{PAB})$ accreditation for eroding the quality of university undergraduate accounting education in the United Kingdom (UK). Critiques argue that $\mathrm{PAB}$ accreditation drives vocational content into degree programmes, leaving less room for more generic skills befitting of a university education (Paisey and Paisey, 2004). In the UK, the system of accreditation is accused of being a major contributing cause of the 'poverty of accounting discourse' (Chambers, 1999, p. 250). Accreditation is said to 
constrain university accounting education so that it emulates professional syllabi and examinations (Hopper, 2013) and is accused of being part of an accounting education system that is failing to adequately equip the accountancy profession for the future (Flood, 2014). This study investigates the extent of accreditation across the UK university sector and considers the views of academics involved in the running of undergraduate accounting programmes, with the intention of answering the following research question:

\section{To what extent is UK university undergraduate accounting education effected by PAB accreditation?}

This article is important for a number reasons. Firstly, it affirms previous claims that 'virtually all undergraduate accounting programmes in the UK are accredited by two or more professional accountancy bodies' (Stoner and Sangster, 2013, p. 296) and establishes why universities take up the accreditation. Secondly, it gives insights into the effect of accreditation on UK accounting degrees, and in so doing, provides a picture of the state of UK university accounting education, establishing that the syllabi and assessment on accounting degrees imitate PAB qualifications, often to a significant level. Thirdly it summarises suggestions from academics on possible alternatives for UK accounting degree programmes (if the constraints imposed by accreditation were removed or altered) and provides suggestions on how university education might better contribute to subsequent professional accountancy training, taken up by many graduates. The article is of potential interest on an international level as the conditions influencing UK accounting degrees, and the views of UK academics on the effects of $\mathrm{PAB}$ accreditation and related issues are of potential interest to those in other jurisdictions investigating accounting degree education. 
This study answers the research question by firstly performing accreditation searches on PAB websites to establish the extent of accreditation at the university level, by degree type and at subject level. Secondly, 18 academics from 12 universities across the sector are interviewed with the intention of confirming the accuracy of the PAB website information on the extent of accreditation, to ascertain how the accreditation is accommodated within their universities governance procedures and to obtain their views on the effects of accreditation. The interviews sought to understand how academics perceive the contentions, contradictions, and complements of the accredited accounting degree as a route into the accountancy profession. Three themes emerged in the findings: (1) why accreditation is taken up, (2) the perceived issues with accreditation and (3) what the accounting degree route into the profession could look like. Finally, the study consolidates the findings, by discussing the impact of accreditation on UK undergraduate accounting degrees and the wider implications for the accountancy profession of UK accounting degrees imitating professional syllabi and examinations.

\subsection{Contribution}

References to PAB accreditation in the UK made in the literature consists of the authoritative opinion of the authors, gained from their experience of working in the UK university sector. This study fills a gap in the literature by providing empirical data from PAB websites on the extent of accreditation and by gathering the views of academics on the effects of accreditation on a broad range of universities across the UK. The article also adds to the literature by providing a contextual background to the diverse UK university sector and how accreditation affects the various types of universities. Importantly this study provides new insights on the contentions, contradictions and contrasting narratives that accreditation generates amongst academics in the UK. 


\subsection{Structure of the article}

The next section of this article reviews the literature relevant to the accreditation of UK accounting degrees. The detail of the interviews and methodology for collecting and assessing the data is set out in section three. The findings are provided in section four. Firstly, the findings section provides relevant background information about UK PABs, the UK university sector and factual information on the amount of accreditation. Secondly, it presents the information gathered from the interviews with academics, initially, to confirm the factual information about accreditation and then proceeding, to analyse the opinions of the academics into the three themes: (1) why accreditation is taken up, (2) the perceived issues with accreditation and (3) what the accounting degree route into the profession could look like. The article is concluded with a discussion and summary of the significant findings from the research.

\section{Literature review}

This review starts with a discussion of the demands placed on accounting degrees from a variety of sources including the academic governance frameworks regulating UK accounting degrees. It considers responses to those demands from different stakeholder groups, including PABs, academics and accounting education researchers. It then explores the topics, relevant to accreditation, that have emerged in the literature since Gray, Collinson, French, McPhail and Stevenson (2001) observed that 'very little systematic research has been undertaken into the impact of accreditation on accounting degrees' (p. 112).

\subsection{Governance frameworks}

The subject benchmark statement from the Quality Assurance Agency for Higher Education (QAA) 'defines what can be expected of a graduate in the subject' (2015a). 
The QAA describe themselves as the body which conducts reviews of higher education providers for compliance and standards (2015b). Universities perform continuous monitoring along with five/six-yearly assurance reviews. The QAA acknowledges that accounting degrees are 'neither a necessary nor a sufficient condition for progress towards a professional qualification and the content of degrees is not prescribed by professional bodies' (2015a, section 5).

Comparing the QAA benchmark statement for accounting to the international standards produced by the International Accounting Educations Standards Board (IAESB) (IAESB, 2014) confirms the opinion of Crawford, Helliar and Monk, (2011) who found 'a degree of overlap' (2011, p. 119) and concluded that IAESB's requirements clearly exceed the QAA. Crawford et al. (2011) conclude that IAESB education standards make no specific distinction of where knowledge or skills should be developed. This is reflective of the IEASB's global remit and the fact that accounting education systems vary by country (Calhoun and Karreman, 2014). In many countries degree entry to PABs is a prerequisite whereas the UK profession has a mix of degree and direct entry (Apostolou and Gammie 2014). The consequence is that UK accounting degrees 'will have a range of aims'(QAA, 2015a) from prerequisite for student exemptions from PAB exams to a more general purpose as an introduction to the world of business, accounting and finance.

\subsection{Stakeholders}

The view from the profession, as set out by Peter Wolnizer the chair of the International Accounting Education Standards Board, is that there are increasing demands on accounting education if it is to remain adequate for the needs of the profession and requirements of society more widely. Wolnizer (2014) identifies the drivers of these demands as: the increasing cross-disciplinarity of accounting education, 
employers' demands for soft skills and an increasingly complex technical base. Flood (2014) identifies the following inadequacies: failure to keep up with the requirements of employers for technical knowledge and generic skills, inability to develop values and attitudes appropriate for lifelong learning and twenty-first century professional practice, and failure to promote critical thinking and intellectual development. Furthermore, there is a lack of consensus about the priorities for addressing these problems. Flood contrasts the main priority of the PABs and employers who are primarily concerned to fill a perceived gap between 'what is taught and what is practiced' (p. 90), with the concern of academics to address what Chambers (1999) described as the 'poverty of accounting discourse' (p. 250). This is illustrative of a broader dichotomy arising from 'tensions within the institutional infrastructure around accounting' (Pierce, 2014, p. 610) such as the long-standing separate agendas from the profession, the PABs, and the accounting academics described by Evans (2014). Paisey and Paisey (2004) explained the influence UK PABs exert on UK accounting degrees through the system of accreditation leaves little room for academics to develop the more liberal approach befitting of a university education. Stoner and Sangster (2013) found that 'virtually all undergraduate accounting programs in the UK are accredited by two or more professional accountancy bodies' (p. 296). The combination of the PAB's influence and reach mean that accreditation can be identified as a key-contributing factor to explain why accounting education in UK universities fails to respond to the calls for change made in the accounting literature (see, for example, Apostolou and Gammie, 2014; Duff and Marriott, 2012; Hopper, 2013; Paisey and Paisey, 2004; Wilson, 2011).

\subsection{The impact of accreditation}

The literature (Paisey and Paisey, 2014; Wilson, 2011) identifies three phases of accounting education relevant to the discussion of professionally accredited accounting 
degrees:

(1) initial professional development (IPD) at university,

(2) IPD in the form of professional training after university and

(3) continuing professional development (CPD).

The purpose of accreditation is to ensure that students are not required to repeat IPD activities completed at university when they undertake their professional training. However, the tension in locating and fulfilling these elements of the IPD phase produces 'some accounting graduates who are well-educated but under-trained, and some who are well-trained but under-educated' (Sudrum, 2014, p. 625) depending on whether they were being prepared in the short term to pass exams or for more long-term and broader benefit. Wilson (2011) critiques the UK approach of accredited accounting degrees as comparable to a retail offer ('two-for-the-price-of-one or buy-one-get- onefree' (p. 5)). Hopper (2013) too reproaches higher education institutions (HEI's) which fail to invest adequately in accounting as a degree subject, instead using it as a 'cash cow' (p. 130) to cross-subsidise university finances. Furthermore, Hopper goes on to state that despite student expectations 'an accounting degree yields few fast track advantages' (2013, pp. 130 - 131), a point with which Apostolou and Gammie (2014) and Koh (2014) concur.

Paisey and Paisey (2004) recommend that accounting educators could learn much from trends developed in the other professions, specifically medicine and law, where academics and the profession have cooperated to develop a "core-plus" degree structure. They observe that the UK PABs are not engaged in the debate on the purpose of university accounting education and that the first step would be for academics and PABs to agree on a core university curriculum. However such developments are not forthcoming, due to the structural issues discussed earlier in this literature review as 
well as a lack of awareness of the potential opportunity available from developing the accounting degree route into the profession. It might also be pointed out that since the demise of the Board of Accreditation of Accountancy Educational Courses (BAAEC) (see Apostolou and Gammie, 2014) there is not an obvious organising body to coordinate such an agreement.

The view that PABs are responsible for the current state of accounting education while academic accountants lack the ability to intervene effectively contrasts with evidence that resistance to reform comes from within the universities. Gray et al. (2001) found the PABs reluctant to embrace a curriculum that adequately covered environmental issues, evidencing the PABs resistance to change. By contrast, Parker (2007) cites reports of accounting academics engaging in 'passive resistance' (p. 44) to reform and describes how Australian academics responded to an 'accounting profession [that] has been progressively loosening it degree accreditation requirements' (p. 44) by preserving the traditional number-crunching approach.

Duff and Marriott (2012) summarise the established status quo in which accreditation produces relatively homogenous, technical university curricula that mitigate against deep learning. The market for accounting degrees reduces the scope for effective intervention of individual universities and 'leaves relatively little space for the development of research skills or the acquisition of contemporary thinking within the discipline' (p. 60). The literature outlined above summarises the existing situation relevant to the accreditation of UK accounting degrees, forming a backdrop to the findings from the empirical interviews with academics from 12 universities across the UK. While the literature review helped shape the semi- structured interview questions, the three themes arising from the analysis of the interviews, arose innately from the 
interviews and were not directly influenced by the literature. The next section sets out the methodology underlying the research.

\section{$3 \quad$ Methodology}

This research was initiated to understand the extent of PAB accreditation in UK universities and to canvass the views of academics within the sector. It, therefore, adopts a qualitative approach, consisting of semi-structured interviews. It seeks to understand how academics perceive PAB accreditation's impact on the accounting degree programmes with which they are involved.

\subsection{PAB website information}

It was discovered early in the process that each $\mathrm{PAB}$ maintains details on their websites of their accreditation by university, degree programme, and subject. This information was anticipated to be an accurate record of the accreditation status of each university with each PAB and was used as a backdrop to interviews with academics. The interviewees were asked to confirm its accuracy as part of the semi-structured interviews.

\subsection{Semi-structured interview questions}

Semi-structured interviews have been used in a number of recent accounting education research projects for collecting information from academics (see, for example, Beattie and Smith, 2012; Duff and Marriott, 2012), thus providing a good precedent for their use. It was considered that semi-structured interviews would provide an appropriate method for collecting the views of academics, giving structure while providing room for 'digressions and expansions, new avenues to be included, and further probing to be undertaken' (Cohen, Manion and Morrison, 2011, p. 236). 
The semi-structured interview questions and technique used in data collection and analysis were designed based on principles set out in established texts for education research, such as systematically working through the stages of planning interviewbased research and considering different categories of question (Cohen et al., 2011), probing, prompting but eliminating inappropriate cues or leading questions (Robson, 2011). The questions were reviewed, refined and piloted, prior to being finalised. The factual opening questions focused on collecting information about the interviewees' universities accounting degree programmes: student numbers, demographics and work placements, length of programme and recruitment trends. Each interviewee was asked about university academic governance procedures and how PAB accreditation requirements are accommodated within each university's academic governance procedures.

The next group of questions were designed to elicit the views of academics on the impact of accreditation and why it was taken up, effectively looking to confirm the accuracy of the opinions expressed in the literature; For example that academics 'bemoan' (Apostolou and Gammie, 2014 p. 669) the impact of accreditation on their programmes. Asking why accreditation with certain bodies or subjects was not sought elicited views on the aims of the PAB's concerning accreditation and how accounting degrees programmes were perceived to be influenced by accreditation.

The final group of questions, also derived from the literature (in particular Paisey and Paisey, 2004; Wilson, 2011), sought to understand the effect of accreditation within the broader context of an accountant's early professional development. The questions solicited views from the academics on graduate knowledge, competencies and skills, whether the academics considered their graduates to be equipped to join the profession and if accounting degrees were complementary or contradictory to a trainee 
accountant's education. Finally, the interviews concluded by asking how the interviewee would design the relevant accounting degree route into the profession and if they wished to add any final comments or information.

\subsection{Ethics}

Ethics clearance for the research was obtained from the authors' university. The salient ethical issue is ensuring the anonymity of the interviewees, whose involvement is voluntary. The interviewees each signed a letter of consent, which explained among other things the purpose of the research and their role in it.

\subsection{Interviews}

All the interviews were conducted by the same researcher and were a combination of face-to-face and telephone interviews. Consistency across the different interview formats was maintained by following the semi-structured interview questions, which the interviewees were given ahead of the interviews. The interviewees were encouraged to talk openly in response to the questions, with prompts and further questions for clarification, thereby seeking rich descriptions regarding the academics' views on dimensions of the topics raised. The interviews were conducted between January and June 2014, took between 45 minutes and one-hour each and were recorded and transcribed verbatim from audiotapes by a professional transcriber. The transcripts were then analysed thematically using NVivo, a qualitative data analysis software package. The emergent themes are rooted in the interview questions (themselves derived from the literature on accreditation) and in the interview data. The analysis performed in NVivo produced 50 sub-themes, which were reviewed for commonality and from which the three major thematic groups discussed in the findings arose. 
Consistent with the iterative cycle outlined by Hennick at al (2011), when reanalysing the interview transcripts for the secondary data analysis it became apparent that the analysis stage was dependent on the design and collection stages. The interview transcripts were often induced by the interview questions, which had been influenced by the design and background investigations. This is also borne out by Miles and Huberman (1994:298) who also point to the 'circular' linkage between questions, methods, data collection and interim analysis as each stage opens up new leads.

Along with information gathered from the fact-finding questions, the themes arising from the data analysis form the structure for the findings section. Details of the interviews by university are provided in Table 4 .

\subsection{Universities and academics interviewed}

In order to explore accounting accreditation in UK universities the selection of HEIs aimed to cover a range of circumstances as described in more detail below. The intention was to give as much breadth to the study as possible within time and resource constraints. The geographic spread included England, Scotland, Wales and Northern Ireland, thereby covering the countries in the UK. From the initial data collection from PAB websites, it was evident that the accreditation at pre-1992 "research" universities and post-1992 "teaching" universities are different. Post-1992 universities do not focus on Institute of Chartered Accountants in England and Wales (ICAEW) or Institute of Chartered Accountants of Scotland (ICAS) accreditation as a rule and hence it appeared important to obtain an equal number of interviews with each of the university types, to better understand the view of academics from across the university sector. As academics from post-1992 "teaching" universities are less likely to be involved in research, it was considered that information from these universities would also fill a gap in the existing literature, which has previously focused mainly on "research" 
universities.

Interviewees were approached through contacts of the authors and via members of the British Accounting and Finance Association Accounting Education Special Interest Group. The individuals were not specifically selected, rather, on the universities contacted acted as gatekeepers directing enquiries towards the academic responsible for accreditation (the academic responsible for accreditation was often also responsible for the accounting degree programmes). Where two or more interviews took place at one university, the initial interviewee put the others forward.

\section{$4 \quad$ Findings}

The findings start by setting out the publicly available data on accreditation gathered from the PAB websites at a UK level before providing data at the institutional level for the 12 universities involved in the study. These observations are elaborated by analysing what the academic interviewees said about the extent of accreditation and how accreditation was facilitated within each university's governance procedures. Finally, this section reports on the three themes emerging from the interview data:

(1) why accreditation is taken up;

(2) the perceived issues with accreditation, and;

(3) what the accounting degree route into the profession could look like.

\subsection{Publicly available data}

\subsubsection{National accreditation data}

In this section relevant facts about the UK accountancy profession, the UK university sector and the extent of accreditation are presented.

The main entry routes into the UK accountancy profession are directly from secondary school ${ }^{3}$, from relevant accounting degrees or from non-relevant degree 
programmes. To enter the accountancy profession trainee accountants may choose to register with any of the seven PABs in the UK. Each body has its own examination and professional-practice training and qualification schemes, which will lead to subsequent membership with that PAB. Studying accounting at university is not a compulsory requirement for entry into the UK accountancy profession as a trainee (Calhoun and Karreman, 2014) ${ }^{4}$. The PABs compete for students; this competition extends to the use of exemptions ${ }^{5}$ from professional examinations as a means of attracting students from relevant degrees. This leads as a consequence to widespread accreditation of undergraduate accounting degrees (Stoner and Sangster, 2013).

The distinction between pre-1992 "research" universities and post-1992 "teaching" universities is an important background factor in understanding the system of accreditation in the UK (Stoner and Sangster, 2013), as the ICAEW and ICAS recruit principally from pre-1992 "research" universities (with a few exceptions). Another important distinguishing factor exists in Scotland where four-year programmes (compared to the elsewhere in the UK where three-year programmes are the norm) providing an opportunity for the 'inclusion of higher-level contemporary material and the development of higher-level skills' (Duff and Marriott, 2012 p. 60).

Table 1 sets out key facts relating to accreditation of universities by the larger PABs in the UK.

Table 1. Relevant facts about major UK PABs

\begin{tabular}{|l|c|c|c|c|}
\hline & ACCA & CIMA & ICAEW & ICAS \\
\hline UK Members 2013 ‘000 & 80.4 & 74.9 & 120.5 & 17.2 \\
\hline Worldwide membership 2013 ‘000 & 165.6 & 95.9 & 142.3 & 20.1 \\
\hline $\begin{array}{l}\text { UK and R.O.I. Registered students 2013 } \\
\text { '000 }\end{array}$ & 85.3 & 55.3 & 15.6 & 3.0 \\
\hline Worldwide students 2013 ‘000 & 365.5 & 122.4 & 20.1 & 3.0 \\
\hline Students holding degrees & $48 \%$ & $51 \%$ & $81 \%$ & $98 \%$ \\
\hline Students holding "relevant” degrees ${ }^{\mathrm{a}}$ & $45 \%$ & $40 \%$ & $18 \%$ & $43 \%$ \\
\hline
\end{tabular}




\begin{tabular}{|l|c|c|c|c|}
\hline Passes at final examinations 2013 & $54 \%$ & $53 \%$ & $75 \%$ & $89 \%$ \\
\hline Number of universities accredited & 150 & 106 & 75 & 12 \\
\hline Subjects available for accreditation & 9 & 11 & 8 & 10 \\
\hline $\begin{array}{l}\text { Total number of subjects in professional } \\
\text { examinations }\end{array}$ & 14 & 14 & 15 & 5 \\
\hline $\begin{array}{l}\text { a The definition of relevant degree varies by body: ACCA = Accountancy and Business, CIMA = Business } \\
\text { Studies, Business Administration, Finance and Accountancy, ICAEW = Accountancy and Finance, and ICAS = } \\
\text { Accountancy. }\end{array}$
\end{tabular}

Sources: ACCA, 2014; ICAEW, 2014; ICAS, 2014; CIMA, 2014 and FRC, 2015.

Membership information provides a comparative guide to size based on number of qualified members and number of students. On that basis the Association of Chartered Certified Accountants (ACCA) and ICAEW are the largest bodies. Degree entry into the profession shows a higher proportion of ICAEW and ICAS members holding degrees compared to ACCA and the Chartered Institute of Management Accountants (CIMA). The proportions of students joining ICAEW and ICAS without relevant degrees are greater than the proportions with a relevant accounting degree. For all four bodies (ACCA, CIMA, ICAEW and ICAS) less than half of the student membership comprises graduates holding relevant degrees.

In 2014/15 the Higher Education Statistics Agency (HESA) (http://www.hesa.ac.uk) recognised 161 UK higher education providers, 150 of whom had ACCA accreditation (ACCA, 2014). ICAEW accreditation relates primarily to English "research" universities and ICAS accreditation is primarily for Scottish "research" universities. The subjects available for accreditation vary by body. Table 2 sets out which exemptions are normally available under accreditation. CIMA provides the most subjects, 11 out of 17, while ICAS provides the least, 5 out of 10 .

Table 2. Exemptions normally available from each PAB

\begin{tabular}{|l|l|l|l|}
\hline PAB & Level & $\begin{array}{l}\text { No./ } \\
\text { Total }\end{array}$ & Subjects normally available for exemption \\
\hline ICAEW & Certificate & $6 / 6$ & $\begin{array}{l}\text { Accounting, Assurance, Business and Finance, } \\
\text { Law, Management Information, Principles of } \\
\text { Taxation. }\end{array}$ \\
\hline
\end{tabular}




\begin{tabular}{|c|c|c|c|}
\hline ICAEW & Professional & $2 / 6$ & $\begin{array}{l}\text { Business Strategy, Financial Management. } \\
\text { Audit and Assurance, Financial Accounting } \\
\text { and Reporting, Tax Compliance, Business } \\
\text { Planning: Taxation are not normally } \\
\text { exempted. }\end{array}$ \\
\hline ICAS & Competence & $5 / 6$ & $\begin{array}{l}\text { Financial Accounting, Principles of Auditing } \\
\text { and Reporting, Finance, Business Law, } \\
\text { Business Management. } \\
\text { Principles of Taxation is not exempted. }\end{array}$ \\
\hline ACCA & Knowledge & $3 / 3$ & $\begin{array}{l}\text { Accounting in Business, Management } \\
\text { Accounting, Financial Accounting. }\end{array}$ \\
\hline ACCA & Skills & $6 / 6$ & $\begin{array}{l}\text { Corporate and Business Law, Performance } \\
\text { Management, Taxation, Financial Reporting, } \\
\text { Audit and Assurance, Financial Management. }\end{array}$ \\
\hline CIMA & Certificate & $4 / 5$ & $\begin{array}{l}\text { Management Accounting, Financial } \\
\text { Accounting, Business Economics, Ethics } \\
\text { Corporate Governance and Business Law. } \\
\text { Business Maths is not normally exempted. }\end{array}$ \\
\hline CIMA & Operations & $4 / 4$ & $\begin{array}{l}\text { Financial Operations, Performance } \\
\text { Operations, Enterprise Operations, Case } \\
\text { Study. }\end{array}$ \\
\hline CIMA & Management & $3 / 4$ & $\begin{array}{l}\text { Financial Management, Performance } \\
\text { Management, Enterprise Management. } \\
\text { Case study is not exempted. }\end{array}$ \\
\hline
\end{tabular}

Duff and Marriott (2012), made the point that Scotland provided a contrast to the norm, forming a natural experiment on what happens when accreditation does not dominate the university curriculum, as there is less accreditation and a four-year programme. They comment:

With the accredited material covered, staff can develop bespoke optional courses and courses at honours level aligned to their own research interests and perceived needs of students in future years. (Duff and Marriott, 2012, p. 46) 


\subsubsection{Institutional data}

The interviewees confirmed the accreditation information at each of their universities, with minor amendments. Table 3 presents this data.

Table 3. Exemptions potentially available for students on programmes at each university from the three largest PABs

\begin{tabular}{|c|c|c|c|c|c|c|c|}
\hline \multirow{2}{*}{$\begin{array}{c}\text { University } \\
\text { Code }\end{array}$} & \multicolumn{2}{|c|}{ ACCA } & \multicolumn{3}{|c|}{ CIMA } & \multicolumn{2}{|c|}{ ICAEW } \\
\hline & Knowledge & Skills & Certificate & Operations & Management & Certificate & Professional \\
\hline 1 & 3 & 6 & 4 & 4 & 3 & 6 & $1^{a}$ \\
\hline 2 & 3 & 6 & 4 & $2^{b}$ & 0 & 6 & 2 \\
\hline 3 & 3 & $1^{\mathrm{c}}$ & 4 & $2^{b}$ & 0 & 6 & 0 \\
\hline 4 & 3 & 6 & 4 & $2^{b}$ & 3 & 6 & $1^{a}$ \\
\hline 5 & 3 & $5^{d}$ & 4 & $3^{e}$ & 0 & $5^{f}$ & 0 \\
\hline 6 & 3 & 6 & 4 & 4 & 3 & 6 & 2 \\
\hline 7 & 3 & 6 & 4 & 4 & 3 & 6 & 0 \\
\hline 8 & 3 & 6 & 4 & 4 & 3 & 6 & 2 \\
\hline 9 & 3 & 6 & 4 & 4 & 3 & $5^{g}$ & 2 \\
\hline 10 & 3 & 6 & 4 & $1^{\mathrm{h}}$ & 0 & 6 & 0 \\
\hline 11 & 3 & 6 & 4 & $2^{b}$ & 3 & 6 & 2 \\
\hline 12 & 3 & 6 & 4 & $2^{b}$ & $2^{i}$ & 6 & $1^{j}$ \\
\hline Max $^{k}$ & 3 & 6 & 4 & 4 & 3 & 6 & 2 \\
\hline $\begin{array}{l}\text { a Business S } \\
\text { b Financial C } \\
{ }^{c} \text { Corporate } \\
{ }^{\mathrm{d}} \text { All Skills p } \\
\text { e All Operat } \\
{ }^{f} \text { All Certific } \\
{ }^{\mathrm{g}} \text { All Certific } \\
{ }^{\mathrm{h}} \text { Financial } \\
\text { i Financial N } \\
\text { j Financial N } \\
\text { k See Table }\end{array}$ & $\begin{array}{l}\text { ategy } \\
\text { berations, } \\
\text { nd Busine } \\
\text { bers excep } \\
\text { ns papers } \\
\text { e papers } \\
\text { te papers } \\
\text { berations } \\
\text { anagemen } \\
\text { nagemen }\end{array}$ & $\begin{array}{l}\text { rforn } \\
\text { Law } \\
\text { Corpo } \\
\text { xcept } \\
\text { Cept } \\
\text { cept } \\
\text { Perfo }\end{array}$ & $\begin{array}{l}\text { ce Oper } \\
\text { e and Bu } \\
\text { se Study } \\
\text { urance } \\
\text { ance Ma }\end{array}$ & $\begin{array}{l}\text { ions } \\
\text { iness Lau }\end{array}$ & & & \\
\hline
\end{tabular}

All the universities in the study apart from two successfully sought to maximise the ACCA exemptions, the following being typical examples of the way in which this approach was discussed: 
... we've got F1 to F7 inclusive of the ACCA, we're outstanding F8 auditing and F9 financial management, we're after those but obviously the objective is to get them but we haven't got them yet. (Academic \#5)

... with ACCA we've the maximum nine exemptions ... so in other words we would be marketing our course on the basis that a graduate will get the maximum exemptions that it's possible to get from any of those professional bodies.

(Academic \#9)

ICAEW accreditation (in England) was located predominantly in pre-1992 "research" universities, the rationale for this being that ICAEW firms recruit very few graduates from post-1992 universities. The fact that ICAEW and ICAS firms of accountants (in England and Scotland respectively) recruit the top performing students from pre-1992 "research" universities, while the remaining students (intending to take up a career in accountancy) generally take up ACCA and CIMA exemptions, is a dominant feature of the accreditation/exemptions landscape. Pre-1992 "research" universities thus target ICAEW or ICAS accreditation as they wish to recruit students who aspire to join ICAEW and ICAS accountancy firms. In addition pre-1992 and post-1992) seek maximum ACCA and some CIMA accreditation giving other students an accredited route into the accountancy profession.

Not all the universities interviewed maximised the exemptions available from ICAEW, ICAS or CIMA (see Table 3). The principle reason for not taking up all available accreditation with these bodies was practicality, for example not being able to get members of faculty to align their modules to the curriculum content or assessment requirements. All universities in the study had a strategy of targeting exemptions to those relevant to each university's student population type as described above, rationalised on the basis that accreditation is perceived as key to student recruitment. Only one university in the study did not seek to maximise exemption, wanting to avoid 
accredited subjects in the final year of their degree programme. This university had low student numbers, gap year work placements, and good career performance, factors mitigating the need for accreditation to support student recruitment or graduate careers.

Consistent with the above, three of the post-1992 "teaching" universities did not have any ICAEW accreditation at the professional level, and the other three did not have full coverage at that level because few of their students have the school entry grades required of ICAEW or ICAS firms of accountants. CIMA accreditation rarely extended beyond the certificate level, often being perceived as of lower importance and thus only being pursued after the primary requirements of students for ACCA or ICAEW/ICAS accreditation had been met. In two instances the reason given for not applying for higher-level CIMA papers was to leave room for more academic content in the programme.

The academics were asked about academic regulations and controls and confirmed how the QAA ${ }^{6}$ processes operated within their university; the unanimous response was that there was no contradiction between their university procedures and accreditation, which could be accommodated alongside other aspirations for degree programmes. Where tensions arise, they appear to be within individual modules rather than at the programme level.

When enquiring about the effects of accreditation on curriculum and assessment, the consensus of opinion was that accreditation constrained the syllabus towards the PAB accredited subjects. Module options exist (more so in pre-1992 universities), however, students opted to obtain maximum accreditation and in doing so reduced the importance of non-accredited modules. Seven academics mentioned that assessment processes were significantly impacted by the PAB examination requirements, saying that their assessment options were restricted by end-of-module examinations. 


\subsection{Themes emerging from the interviews}

Table 4. Interviews

\begin{tabular}{|c|c|c|c|c|c|}
\hline $\begin{array}{l}\text { University } \\
\text { Code }\end{array}$ & $\begin{array}{l}\text { Type of } \\
\text { university }\end{array}$ & $\begin{array}{l}\text { Student } \\
\text { numbers }\end{array}$ & $\begin{array}{l}\text { Interview } \\
\text { code }\end{array}$ & Position & $\begin{array}{l}\text { Male/ } \\
\text { Female }\end{array}$ \\
\hline \multirow[t]{3}{*}{1} & \multirow[t]{3}{*}{ Pre-1992 } & \multirow[t]{3}{*}{150} & 1 & Lecturer & $\mathrm{M}$ \\
\hline & & & 2 & $\begin{array}{l}\text { Senior } \\
\text { Lecturer }\end{array}$ & $\mathrm{M}$ \\
\hline & & & 3 & $\begin{array}{l}\text { Senior } \\
\text { Lecturer }\end{array}$ & $\mathrm{M}$ \\
\hline \multirow[t]{2}{*}{2} & \multirow[t]{2}{*}{ Pre-1992 } & \multirow[t]{2}{*}{85} & 4 & $\begin{array}{l}\text { Principle } \\
\text { Lecturer }\end{array}$ & $\mathrm{F}$ \\
\hline & & & 5 & Lecturer & $\mathrm{M}$ \\
\hline \multirow[t]{2}{*}{3} & \multirow[t]{2}{*}{ Post 92} & \multirow[t]{2}{*}{40} & 6 & $\begin{array}{l}\text { Head of } \\
\text { Department }\end{array}$ & $\mathrm{M}$ \\
\hline & & & 7 & $\begin{array}{l}\text { Senior } \\
\text { Lecturer }\end{array}$ & $\mathrm{F}$ \\
\hline 4 & Post 92 & 85 & 8 & $\begin{array}{l}\text { Senior } \\
\text { Lecturer }\end{array}$ & $\mathrm{M}$ \\
\hline \multirow[t]{2}{*}{5} & \multirow[t]{2}{*}{ Post 92} & \multirow[t]{2}{*}{90} & 9 & $\begin{array}{l}\text { Head of } \\
\text { Dept. }\end{array}$ & $\mathrm{F}$ \\
\hline & & & 10 & $\begin{array}{l}\text { Senior } \\
\text { Lecturer }\end{array}$ & $\mathrm{F}$ \\
\hline 6 & Pre-1992 & 150 & 11 & $\begin{array}{l}\text { Senior } \\
\text { Lecturer }\end{array}$ & $\mathrm{F}$ \\
\hline \multirow[t]{2}{*}{7} & \multirow[t]{2}{*}{ Pre-1992 } & \multirow[t]{2}{*}{100} & 12 & $\begin{array}{l}\text { Senior } \\
\text { Lecturer }\end{array}$ & $\mathrm{F}$ \\
\hline & & & 13 & $\begin{array}{l}\text { Senior } \\
\text { Lecturer }\end{array}$ & $\mathrm{M}$ \\
\hline 8 & Pre-1992 & 150 & 14 & Professor & $\mathrm{M}$ \\
\hline 9 & Pre-1992 & 100 & 15 & Lecturer & $\mathrm{M}$ \\
\hline 10 & Post 92 & 250 & 16 & $\begin{array}{l}\text { Senior } \\
\text { Lecturer }\end{array}$ & $\mathrm{F}$ \\
\hline 11 & Post 92 & 105 & 17 & $\begin{array}{l}\text { Principal } \\
\text { Lecturer }\end{array}$ & $\mathrm{M}$ \\
\hline 12 & Post 92 & 200 & 18 & $\begin{array}{l}\text { Principal } \\
\text { Lecturer }\end{array}$ & $\mathrm{F}$ \\
\hline
\end{tabular}

In the above table type of university relates to whether the university is a pre-1992 “research" university or a post-1992 "teaching” university².

\subsubsection{Why accreditation is taken up}

Participants were asked about their local accreditation/exemptions strategy, questions which elicited discussion around why a business school might or might not seek 
exemptions. There was accord from the academics interviewed that accreditation is used by PABs to attract and prepare graduates for student membership of their bodies by giving them credit for prior study, setting consistent curriculum, consistent examinations, maintaining standards and providing a rigour and professionalism to accountancy degree programmes. The academics were generally complicit with the PABs intentions, seeing accreditation as a fait accompli.

\subsubsection{Student recruitment}

Many academics (twelve of the eighteen) said that accreditation is essential for student recruitment to accounting degree programmes and that it is used more or less explicitly to indicate quality and employability for the degree programmes. However, accreditation as a source of competitive advantage for specific degree programmes is problematic as all universities across the sector have it. As one of the department heads interviewed put it

You could theoretically have a degree without any accreditation, in practice it would be a bit of a nonsense to offer an accounting degree without accreditation, so parts of the rationale for the degree in the first place means establishing a market for it and the market for it is driven by accreditation. (Academic \#6)

So, contrasted with the stance that places accreditation at the heart of an accounting degree programme, there is an alternate, and in our discussions widely held view, that 'educationally it would be good to get rid of exemptions but it would be suicide from a recruitment point of view' (Academic \#8) or 'it would be marketing suicide to say that you don't have exemptions and accreditation' (Academic \#7). Academics \#7 and \#8, who both employed the vivid metaphor of suicide, were from two different post-92 institutions. 
It was apparent that academics involved in accounting programmes are well aware of what is being offered by other universities: one academic who had reviewed the competitors while making improvements to their own programme had concluded that 'if you want to be seen to have a good accounting finance [sic] behind you that degree has got to at least have everything available from the ICAEW and F1 to F9 of the ACCA' (Academic \#4).

A widespread attitude (eight of the eighteen participants) towards exemptions was to seek 'maximum accreditation we can get in order to bring in the student numbers' (Academic \#16). The concept of maximum accreditation was widespread among respondents and is both ambiguous and viewed with ambivalence. It links the imperative of business schools to act as what Academic \#3 described as 'cash cows' for a university and therefore to 'create an appealing product in the market' (Academic \#2), with a latent distaste towards exemptions which could be viewed variously as shorttermism, or what Academic \#6 critically described as 'trying to tick as many boxes as possible' and Academic \#15 dismissed as creating 'compliance officers'.

\subsubsection{Employability}

Some saw the exemptions as creating an easy illusion of employability:

If you try to look at anybody's website, it's very subtle but they link employment and accreditation on the same page on lots of universities websites; it's a marketing tool and I don't know who drove it, I think possibly parents are driving it because they don't understand the job market, so I think it's, and nobody can break free, you can't say well sorry we're not going for accreditation. (Academic \#7)

In universities which did not have maximum exemptions outside of ACCA the policy seems to be to apply for those exemptions which are easily obtained from their programme content but to not apply for accreditation if it was considered onerous to 
obtain, by for example, aligning colleagues to match syllabi and assessment to the PABs professional examinations to meet what they considered to be rigid the requirement for accreditation.

\subsubsection{Flexibility of PABs}

Perceptions of PABs inflexibility might be grounded in the history of specific universities' accounting programmes. Some programmes had historically been aligned more to one PAB than another, for example pre-1992 "research" universities tended to historically align their programmes around ICAEW and tended to reject changes that might introduce 'yet more technical material' (Academic \#2) at the expense of crowding out desirable features of a degree programme. By contrast, academics at post1992 "teaching" universities who recalled the experience of delivering what were effectively ACCA franchised courses (a model no longer available) considered that relatively stringent requirements from PABs seemed less onerous than what had been required in the past.

\subsubsection{Summary}

The factors perceived as leading to the take up of accreditation are the same in both the "teaching" and "research" universities. The advantages of accreditation tended to be institutional ones (reduced administration, marketing opportunities) but the burden of delivering modules with attached exemptions tended to be felt by individual academics who considered that they were constrained in delivering specific content or undertake assessment in particular ways. 


\subsubsection{Perceived issues with accreditation}

A widespread theme raised by seven of the participants was that when a module or course gains exemptions, something has to be sacrificed. At some point the sacrifice was too great and exemptions would not be sought.

Where we have seen that accreditation would probably pull us out of shape we've stepped back from that, so one of the reasons we have decided not to go for many ACCA exemptions is that they are the most prescriptive of all the bodies.

(Academic \#6)

\subsubsection{Burden of technical material}

There was a widespread concern that exemptions brought more technical material into the syllabus. Gaining an exemption meant sacrificing depth of study for breadth of study.

... if you want the exemption you have to test all there is of the syllabus if you want exemption. And actually I think that students should be free to explore the areas that they find interesting ... I'd rather they did some things excellently than everything in a mediocre fashion. (Academic \#7)

There were a number of features that participants felt were lost with exemptions. These included the space for students to be reflective, critical, theoretical, analytical, more academic, 'space to develop that attitudinal side of what it is to be a good accountant' (Academic \#2), to consider political or social questions.

These points went to the heart of what a degree was about; 'ultimately a degree is an intellectual exercise, it's not a practical training' (Academic \#6). One participant suggested that accreditation undermines the validity of accounting as an academic discipline. 
[if] people didn't sell their degrees based on accreditation ... then we could actually teach the students, you know, more around the subject, be more like a proper university subject. (Academic \#16)

\subsubsection{Status of academics with a background in practice}

Some of the perceived problems of subject exemptions and accreditation seemed to be linked to more subtle, pervasive issues about the place of accounting and professional accountants within the academic community. Exempted papers were often characterised as technical and taught by practitioners rather than academics, for example, referring to the identity of academics in faculty, Academic \#4 mentioned the 'standard academic attitude to the professional accountants'. Participants saw themselves and others in their faculty as either academics or as accountants and it became apparent in the interviews that those who identified themselves as academics rather than as accountants, were more likely to exhibit a cultural resistance to exemptions, for example Academic \#15, active in research, said 'this is not something we want our students to kind of aim for ... I think that we're trying to add some depth to what it is to be an accountant'. The view on the other side of this cultural divide was that some modules

are the strong-hold of academics who prefer a lecture style of teaching, aligned to delivering technical content, whereas the feedback from students is that they prefer tutorials as they feel they learn more that way. (Academic \#4).

Another participant described how familiarity with the profession might make a colleague more amenable to adapting a module to gain exemptions.

... you do rely on people's goodwill when you say well here's the syllabus, do you think you can, you know, introduce $\mathrm{x}, \mathrm{y}$ and $\mathrm{z}$ next year so I can tick this box, and most of the accounting and finance colleagues appreciate this and say yes, but 
somebody providing the business module or the law module, you know, it gets quite hard for them. (Academic \#11)

\subsubsection{Placement programmes}

Comments from universities with placement programmes were generally more positive about the effects of accreditation, seeing a direct link between technical content, workplace practices and the early career aspirations where technical content promoted by accreditation processes helps transition students in their early years in training contracts with firms of accountants. Referring to positive aspects of accreditation a few academics mentioned, and many implied, that it gave structure, relevance for curriculum and a benchmark for standards.

\subsubsection{Relationship between university exams and professional exams}

Discussions often lead unprompted to how students performed in PAB examinations after graduation. Participants at eight different universities observed that their internal examinations were set at a lower level or that they were easier to pass than the professional examinations from which they carried an exemption. Professional exams '... are going to be totally different and probably more demanding than university exams' (Academic \#1). 'The content of our module ... is fine but there's a lack of rigour in our examinations' (Academic \#4). Academic \#7 compared the university and professional exams, 'I don't think that the professional exams are compatible with university exams, and I think university exams by and large are easier' while academic \#17's view was 'I just think there's less pressure on the student generally in university exams compared with professional exams.' A similar view was shared by academic \#18 'I think you might say that to do the exams in the real world is probably a jolly sight harder than getting an accredited pass at university.' 
Four participants explored some of the reason that the university route to getting a professional paper might be perceived to be easier than the professional exam route. The difference might arise form targeting different skills.

I think there's an issue there around the skills they've developed, whether or not they are appropriate for the professional exams because we have spent a lot of time developing their academic skills and their thinking skills. (Academic \#10)

Concern was voiced about the length of time between learning material at university and then using it in professional exams.

If we gave the students [that] exemption we probably wouldn't be doing them any favours. When they then start their professional training, probably the last thing they want is an exemption from [that paper] because then the first time they would see any of this is when they try and sit the case study.... and they'll crash and burn. (Academic \#6)

It was felt that the students getting the best degrees would be able to pass the papers from which they received exemptions.

Whenever I look at an F7 paper I think can my students do this and I think those ones that are getting $70 \%$ in my exam could pass those papers but those ones [who] get through with 40 wouldn't. (Academic \#16)

On the other hand, an academic reported how a high-flying student failed badly in the subsequent professional exams '.. one year we had the student who won the prize for best performance in final year advanced financial reporting then studies P2 and failed it' (Academic \#17) but elaborated that this could be because 'they find it a big step up'.

The issues around the comparability or lack of it between university style assessment and the professional exams concerned some academics because of the expectations that it created around the exemptions. 
[Students] think it sounds like a short cut but I've heard ... that some of the firms will disregard the exemptions and they'll make them sit the modules or the exams anyway, and they probably benefit from that because, well what we do in the traditional academic setting is not going to be the same as what can be done at the professional level. (Academic \#14)

Academic \#5 voiced concern that they didn't track how their top students performed in subsequent professional exams

You don't want to be sending students out with a high degree who then get employed by some of the top firms but then immediately fail the exams ... that's something that we don't currently track, but it's one, you know, that we should look at in future, definitely.

\subsubsection{Summary}

Managing exemptions requires some thought. There are tensions between achieving sufficient coverage of a technical syllabus and providing opportunities for the critical analysis required within an accounting degree. One participant said 'I think it's difficult for people to find the time to what I would call chew the fat, you know, and just talk things over so that issues and solutions emerge' (Academic \#8).

The issues perceived to exist with accreditation show an interesting divergence between academics in "teaching" universities compared with those in "research" universities. Academics at larger "teaching" universities were resigned to teaching accredited courses with a technical focus but there is evidence that some academics at smaller "teaching" universities are optimistic about managing accreditation within their degree programmes and feel more empowered to do so. Academics in "research" universities meanwhile perceive the same problems with accreditation as their colleagues elsewhere but are pessimistic about their capacity to make the reforms they 
would like to see. There is some evidence that the relative status of teaching and research academics in "research" universities lies behind this.

\subsubsection{What the accounting degree route into the profession could look like}

In the interviews participants were given the opportunity to consider what an accounting degree might look like given a "blank canvas".

When discussing the overall structure of the route into professional practice participants expressed apparently opposing positions: 'I wouldn't have a degree route into the profession' (Academic \#18); 'if the professional bodies did away with exemptions altogether' (Academic \#14); 'I would insist on the relevant-only degree path' (Academic \#13). These positions seem to contradict each other however closer scrutiny reveals that they are all attempting to achieve the same aim which is to give accountants an opportunity to undertake a broader education at university 'it's important that not only do they cover the theoretical stuff but they also have some broader concept of business and society in which they operate' (Academic \#13) coupled with practical experience to support the technical knowledge 'I would get more movement in and out of the university from the profession' (Academic \#10).

Other participants used the "blank canvas" question as an opportunity to consider the problem of when to cover the technical material, so one solution was to structure the degree course so that 'students get introduced to what I would call those broad graduate skills...then we take them to the technical stuff in second year' (Academic \#8). This academic was seeking to contain the technical material and consequently protect academic characteristics of the rest of the programme.

These different stances, (abolishing accounting degrees, abolishing exemptions, mandatory accounting degrees or containing the technical material) all shared a common view that the value of a degree did not lie in the technical content and that 
exemptions inappropriately pushed too much technical material into a degree, which was better covered by the profession.

A truly contrasting view was to embrace the technical and make accounting programmes look more like the professional exams, typified by this participant's remarks.
Well I'd make it more practical. I'd base it on professional exams, I have to say I would have a lot less literature, I wouldn't have none, I certainly wouldn't have as much, I'd maybe have, I don't know, 70\% practical, 30\% literature based. I'd maybe have some more real life scenarios, you know, try and get them even a week in the profession or, I don't know, just make it more like real life and prepare them a bit better for the practical side of the profession I would say. (Academic \#12).

This academic taught on a four-year course, which covered technical material in the first and second years and were more academic in the latter years.

... it takes us two and a half years really to do the technical stuff that's required for accreditation, that gives us another year and a half to give them the more academic literature-based skills. (Academic \#12)

Throughout the discussions the sense was that technical material was a challenge because of its sheer volume but not necessarily demanding in terms of higher-level academic skills. However, none of the participants considered changing the order in which aspiring accountants tackle their education, although one of the participants described their own experience of undertaking a business degree after they had qualified as an accountant.

\subsubsection{Summary}

Academics from both "teaching" and "research" universities shared the concern that too much technical material is potentially detrimental to a degree programme. There is no 
evidence of a particular pattern of potential solutions to this issue emerging in one or other type of institution. Interestingly, the most radical proposal in terms of stripping out academic material in favour of a more technical approach came from an academic working in a "research" university.

\section{Discussion and conclusions}

The objectives of this study are to investigate the extent of accreditation and the perceptions of academics on the impact that it has on UK university degrees and the accountancy profession more widely. It also questions the academics on whether they consider that UK accounting degrees should be given a different purpose other than to imitate professional syllabi and examinations.

The limitations of the research are that while the factual information, extracted mainly from PAB accreditation information available on their websites, appears to be an accurate record of the extent of accreditation, the views of 18 academics may not be a true representation of all academics across the sector. In addition, the interview process is inevitably subject to 'double hermeneutics' (Giddens, 1993, p. 13), in that the academics that were interviewed are interpreting the effects of accreditation and in turn, the authors are interpreting what they meant. Inevitably many of the findings in this article are the authors' interpretations of the opinions expressed by 18 academics, which cannot claim to fully reflect the university sector as a whole. However, the academics interviewed have all had an authentic experience of teaching on UK accounting courses which receive accreditation. We have assumed that they have reported their perceptions of those experiences accurately within the scope of the interviews.

At a macro level, it is confirmed that virtually all UK universities have accreditation and that many have accreditation with three UK PABs. The accreditation of programmes is used by many universities to market their accounting degrees and is 
seen as an important influence on recruitment, without which students might decide to study elsewhere. PABs, in turn, compete for graduates by providing students with accreditation to attract them towards student membership of their professional body.

Accreditation is pervasive, with individual universities having up to nine modules on their programmes linked to exemptions from PAB professional examinations. Academics commented on the constraining nature of the accreditation on their accounting degrees programmes, often stating that it is a fundamental issue with regards their ability to change accounting curriculum, pedagogy, and assessment. Accredited modules fill degree programmes that in turn are filled with the technical content required to meet the requirement of accreditation, leaving little room for the inclusion of generic skills development and wider liberal educational values. The impact on post-1992 "teaching" universities is that students have little choice other than to study accreditation subjects for their degree. At pre-1992 "research" universities, the impact was less stark. While still pervasive, students did have more subject choice to construct the content of their degrees to have less accredited subjects. However, few students took this route, as they wanted to maximise the number of exemptions that they received. This is despite, some accountancy firms recruiting ICAEW students requiring students to retake examinations for which they had exemptions.

The findings confirm the views expressed in the accounting education literature on extent and effects of accreditation and extend the discussion on the implications. Views on what constitutes a good accounting education appeared to depend to a great extent on the interviewee's background and their own route into the profession and into the academy. This viewpoint can also be extended to the opinions expressed by those academics from pre-1992 "research" universities and the accounting education literature, which inevitably comes from "research" universities and consequently leans 
towards academic education standards rather than vocational training. An opposing view put forward by academics with a professional accounting background (who identified themselves more with the accountancy profession than with academia), considered that accreditation provided a structure and disciplined approach to the study of accounting in their universities, which might otherwise not be the case.

Despite, individual academics' views on the merits of accreditation, it was found that curriculum and assessment requirements of accreditation crowded out more liberal approaches to accounting education. The dichotomy appeared to be in finding time alongside accredited modules and content within modules to promote generic skills and more liberal or academic aspects of education. This is evidenced by the "natural experiment' (Duff and Marriott, 2012 p. 46) in Scotland where less accreditation from ICAS and four-year degrees result in a more liberal approach to accounting education.

In looking at relevant accounting degrees in the context of an accounting student's route to being professionally qualified, it was found that exemptions are not necessarily good for the student's further progress onto the professional stages of the PAB qualifications. It was considered that students struggle to adapt to professional examinations after studying at university, and that this was especially true where students do not obtain good honours passes on their accounting degree. The authors consider that, to initiate further investigation into this situation, PABs should be required to publish their pass rates for subsequent professional examinations analysed by university, setting out performance of good honours students compared to pass students, by professional exam subject. Releasing this information would be helpful to all parties and might lead to the restriction of accreditation, where it is proved to be counter-productive to graduates progression in subsequent professional examinations. 
While providing a consistent structure and approach to accounting education, accounting degrees in the UK imitate professional accountancy body examinations, in order to recruit students. The consensus among the academics in our study when reflecting on the relevant accounting degree route into the profession that there should be a substantially reduced level of accreditation is consistent with the views in the literature and in particular to those put forward Paisey and Paisey (2004) and Wilson (2011). There is a missed opportunity at the degree stage to provide a wider liberal education to future accountants. UK PABs are not engaged in the debate on the purpose of university accounting education. Instead, their interface with UK universities is through a system of accreditation, which constrains the potential for accounting degree programmes and the academics that teach on them.

\section{Acknowledgements}

The project received a bursary and support, through workshops and mentoring from the British Accounting and Finance Association Special Interest Group (BAFA SIG) for Accounting Education.

\section{Notes}

1. There are seven professional accountancy bodies (PABs) in the UK: the Institute of Chartered Accountants of England and Wales (ICAEW), the Institute of Chartered Accountants in Scotland (ICAS), Chartered Accountants Ireland (CAI) - which operates in North Ireland a part of the UK, the Association of Chartered Certified Accountants (ACCA), the Chartered Institute of Public Finance and Accountancy (CIPFA), and the Chartered, Institute of Management Accountants (CIMA) and the Association of International Accountants.

2. This historic split results from when polytechnics, specialising in vocational subjects, were granted university status in 1992. Subsequently, they are often referred to as post-1992 "teaching" universities. Pre-1992 universities, in contrast, are known as "research" universities

3. Secondary school is a term used in the UK for educational provision for pupils aged $11-$ 18 years. 
4. In USA and Australia for example an accounting degree is a mandatory requirement prior to taking professional body examinations.

5. The system of accreditation in the UK, operates by universities applying for subject-bysubject exemptions from $\mathrm{PAB}$ professional examinations for students that pass the university module that has qualified for the exemption.

6. QAA, the Quality Assurance Agency for Higher Education (2015) in the UK sets benchmarks for degrees across the sector. The relevant benchmark statement for accounting degrees is the benchmark statement for accounting (QAA, 2015b).

\section{References}

The Association of Chartered Certified Accountants (ACCA). (2014). Exemption Enquiry. Retrieved from https://portal.accaglobal.com/accrweb/faces/page/public/accreditations/enquiry/ main/EnqInstitutionsTable.jspx

Apostolou, B., \& Gammie. E., (2014). The role of accreditation in accounting education and training. In R. M. S. Wilson, (Ed.), The Routledge Companion to Accounting Education (pp. 652 - 672). Abingdon, Routledge.

Beattie, V., \& Smith, S. J. (2012). Today's PhD students - is there a future generation of academics or are they a dying breed? A UK perspective. Edinburgh, Institute of Chartered Accountants of Scotland.

Calhoun, C. H., \& Karreman, G. H. (2014). Comparative accounting education. In R. M. S. Wilson, (Ed.), The Routledge Companion to Accounting Education (pp. 584 - 608). Abingdon, Routledge.

The Chartered Institute of Management Accountants (CIMA). (2014). Exemption search. Retrieved from http://www.cimaglobal.com/Study-withus/Exemptions/Exemption-search/

Chambers, R. J. (1999). The poverty of accounting discourse. Abacus, 35, 241-251.

Cohen, L., Manion, L., \& Morrison, K. (2011). Research Methods in Education [7th edn] London: Routledge.

Crawford, L., Helliar, C., \& Monk, E. A. (2011). Generic skills in audit education. Accounting Education: an international journal, 20, 115-131.

Duff, A., \& Marriott, N. (2012). Teaching and Research: Partners or competitors?, Edinburgh: Institute of Chartered Accountants of Scotland. 
Evans, E. (2014) The interface between academic education and professional training. In R. M. S. Wilson, (Ed.), The Routledge Companion to Accounting Education (pp. 632 -651). Abingdon, Routledge.

Flood, B. (2014). The case for change in accounting education. In R. M. S. Wilson, (Ed.), The Routledge Companion to Accounting Education (pp. 81 - 101). Abingdon, Routledge.

The Financial Reporting Council (FRC). (2015). Key Facts and Trends in the Accountancy Profession, Retrieved from https://www.frc.org.uk/OurWork/Publications/Professional-Oversight/Key-Facts-and-Trends-in-theAccountancy-Profes-(1).pdf

Giddens, A. (1993). New rules of sociological method: A positive critique of interpretative sociologies. Cambridge, Polity.

Gray R., Collison D., French J., McPhail K and Stevenson L. (2001). The Professional Accountancy Bodies and the Provision of Education and Training in relation to Environmental Issues. Glasgow, Institute of Chartered Accountants of Scotland. Hopper, T. (2013). Making accounting degrees fit for a university. Critical Perspectives on Accounting, 24, 127-135. doi: 10.1016/j.cpa.2012.07.001.

The Institute of Chartered Accountants in England and Wales (ICAEW). (2014). Recognised Partners in Learning - HEI's. Retrieved from http://www.icaew.com/en/qualifications-and-programmes/partners-inlearning/icaew-higher-education-institutions/recognised-partners-in-learningheis

The Institute of Chartered Accountants of Scotland (ICAS). (2014). Accredited Degrees, Retrieved from http://icas.org.uk/becomeaca/ICAS_Accredited_degrees/

The International Accounting Education Standards Board (IAESB). (2014). IES Initial Professional Development - (Revised). Retrieved from: http://www.ifac.org/sites/default/files/publications/files/IAESB-IES-2(Revised)_0.pdf

Koh, H. C. (2014). Determinants of students' performance in accounting programmes. In R. M. S. Wilson, (Ed.), The Routledge Companion to Accounting Education (pp. xx - xxi). Abingdon, Routledge. 
Paisey, C., \& Paisey, N. J. (2004). Professional education and skills: liberalising higher education for the professions in the United Kingdom. Research in PostCompulsory Education, 9, 161-182. doi: 10.1080/13596740400200173.

Paisey, C., \& Paisey, N. J. (2014). The state of professional accounting education and training. In R. M. S. Wilson, (Ed.), The Routledge Companion to Accounting Education (pp. 673 - 696). Abingdon, Routledge.

Parker, L.D. (2007). Professionalization and UK accounting education:academic and professional complicity - a commentary on 'Professionalizing claims and the statem of UK professional accounting education: some evidence'. Accounting Education, 16, 43-46. doi: 10.1080/09639280601151044

Pierce, A. (2014). Preface to Institutional considerations. In R. M. S. Wilson, (Ed.), The Routledge Companion to Accounting Education (p. 610). Abingdon, Routledge.

The Quality Assurance Agency for Higher Education (QAA). (2015a). QAA Subject Benchmark in Accounting. Retrieved from http://www.qaa.ac.uk/en/Publications/Documents/SBS-consultationaccounting.pdf

The Quality Assurance Agency for Higher Education (QAA). (2015b). UK Quality Code for Higher Education, Retrieved from http://www.qaa.ac.uk/assuringstandards-and-quality/the-quality-code.

Robson, C. (2011). Real world research: a resource for users of social research methods in applied settings. Chichester, Wiley.

Stoner, G. N., \& Sangster, A. (2013). Teaching IFRS in the UK: Contrasting experiences from both sides of the university divide. Issues in Accounting Education, 28, 291-307. doi: 10.2308/iace-50357

Sudrum, G. L. (2014). Fifty years of change in accounting education: the influence of institutions. In R. M. S. Wilson, (Ed.), The Routledge Companion to Accounting Education (pp. xx - xxi). Abingdon, Routledge.

Wilson, R. M. S. (2011). Alignment in accounting education and training. Accounting education: an international journal, 20, 3-16.

Wolnizer, P. W. (2014). Forward. In R. M. S. Wilson, (Ed.), The Routledge Companion to Accounting Education (pp. xx - xxi). Abingdon, Routledge. 